\title{
Peningkatan Produktivitas Kopi Arabika Gayo I dan II Berbasis Aplikasi Biourine dan Biokompos
}

\section{(Increase Productivities of Coffee Arabica Gayo I and II by Biourine and Biocompost Applications)}

\author{
Asis*, Rizki Ardiansyah, Rachman Jaya, Ishar \\ (Diterima Agustus 2019/Disetujui Agustus 2020)
}

\begin{abstract}
ABSTRAK
Dataran Tinggi Gayo memiliki wilayah yang potensial sebagai pengembangan kopi Arabika karena kondisi topografi lahan yang mendukung budi daya kopi Arabika Gayo, tetapi produksi tanaman berkisar $650-750 \mathrm{~kg} \mathrm{ha}^{-1}$, lebih rendah dari beberapa varietas yang ada pada saat ini yang mencapai $1,5-2$ ton ha-1. Salah satu cara untuk meningkatkan produksi adalah aplikasi biourine dan biokompos. Penelitian ini bertujuan untuk mengetahui pengaruh aplikasi berbagai dosis pemupukan biourine dan biokompos pada peningkatan produksi kopi Arabika Gayo I dan II. Penelitian ini menggunakan Rancangan Petak Terpisah (RPT) pola faktorial, terdiri atas kopi Arabika Gayo I (A1) dan Gayo II (A2) dengan dosis NPK $150 \mathrm{~kg} \mathrm{ha}^{-1}$ (perlakuan petani/kontrol) (C1), $150 \mathrm{~mL}$ plant $^{-1}$ (biourine) +5 ton ha-1 $^{-1}$ (biokompos) + NPK $100 \mathrm{~kg} \mathrm{ha}^{-1}$ (C2), $125 \mathrm{~mL}_{\text {plant }}{ }^{-}$(biourine) $+7,5$ ton ha-1 (biokompos) + NPK $100 \mathrm{~kg} \mathrm{ha}^{-1}$ (C3), dan $100 \mathrm{~mL}^{\text {plant }}{ }^{-1}$ (biourine) +10 ton ha-1 (biokompos) + NPK $100 \mathrm{~kg} \mathrm{ha}^{-1}$ (C4) yang dianalisis dengan ANOVA dan UJBD 95\%. Hasil penelitian menunjukkan bahwa perlakuan dosis pemupukan biourine dan biokompos tidak berinteraksi dengan kopi Arabika Gayo I dan Gayo II, tetapi perlakuan mandiri dosis pemupukan biourine dan biokompos

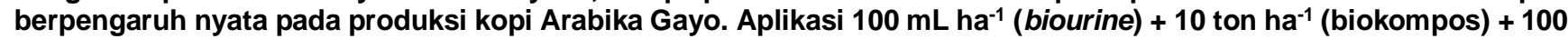
$\mathrm{kg} \mathrm{ha}^{-1} \mathrm{NPK}$ (C4) dapat meningkatkan produksi kopi Arabika Gayo sebesar 41\% jika dibandingkan dengan pemupukan NPK $150 \mathrm{~kg} \mathrm{ha}^{-1}$ tanpa biourine dan biokompos (C1).Hasil analisis regresi menunjukkan bahwa $80 \%$ peningkatan produksi kopi Arabika Gayo dipengaruhi oleh peningkatan dosis biokompos.
\end{abstract}

Kata kunci: Arabika Gayo, biourine, biokompos, produksi

\section{ABSTRACT}

Gayo Highlands region had a potential area for the development of Arabica coffee because of the topographical conditions of the land that support the cultivation of Gayo Arabica coffee, but production of plants ranges from 650$750 \mathrm{~kg} \mathrm{ha}^{-1}$, lower than some existing varieties which reach 1,5-2 tons ha-1. One way to increase production is the application of biourine and biocompost. This study aimed to determine the effect of the application of biourine and biocompost technology packages on the growth and production of Gayo I and II Arabica coffee plants. This study used a factorial separate plot design (RPT) consisting of Arabica Gayo I (A1) and Gayo II (A2) with a dose of NPK 150 $\mathrm{kg} \mathrm{ha}^{-1}$ (farmer/control treatment) (C1), $150 \mathrm{~mL}^{-1}$ (biourine) +5 ton ha-1 (biocompost) $+\mathrm{NPK} 100 \mathrm{~kg} \mathrm{ha}^{-1}$ (C2), $125 \mathrm{~mL}$ plant $^{-1}$ (biourine) +7.5 ton ha $^{-1}$ (biocompost) + NPK $100 \mathrm{~kg} \mathrm{ha}^{-1}$ (C3), and $100 \mathrm{~mL}^{-1 a n{ }^{-1}}$ (biocompost) +10 ton ha $^{-1}$ (biocompost) + NPK $100 \mathrm{~kg} \mathrm{ha}^{-1}$ (C4). The results of the observations were analyzed by ANOVA and 95\% DMRT. The results showed that the doses of biourine and biocompost fertilizers did not have interaction with Gayo I and Gayo II Arabica coffee, but for independent treatment of biourine and bicompost fertilizers, the dosage significantly affected the production of Gayo Arabica coffee. Application of $100 \mathrm{~mL} \mathrm{ha}^{-1}$ (biourine) +10 tons ha-1 (biocompost) $+100 \mathrm{~kg} \mathrm{ha}$ ${ }^{1}$ NPK (C4) was able to increase the Gayo Arabica Coffee production by $41 \%$ when compared with NPK fertilizers of $150 \mathrm{~kg} \mathrm{ha}^{-1}$ without biourine and biocompost (C1). Regression analysis showed that the level of $80 \%$ of Gayo Arabica Coffee was affected by the different application of biocompost dosages.

Keywords: Arabica Gayo, biourine, biocompost, productivity

\section{PENDAHULUAN}

Kopi Arabika Gayo merupakan varietas kopi lokal Gayo sehingga memiliki tingkat adaptasi yang tinggi pada kondisi lingkungan dataran tinggi dengan cita

Balai Pengkajian Teknologi Pertanian Aceh, Jl. Panglima Nyak Makan, No. 27 Lampineung, Nanggroe Aceh Darussalam 23125

*Penulis Korespondensi: Email: asissp_89@yahoo.co.id rasa terbaik. Kopi Gayo telah dikembangkan oleh masyarakat Gayo selama bertahun-tahun dengan sistem budi daya terus menerus sepanjang tahun. Pemanfaatan lahan budi daya selama bertahun-tahun dengan sistem budi daya konvensional menyebabkan penurunan kesuburan lahan sehingga terjadi penurunan produksi kopi. Data Direktorat Jenderal Perkebunan, Kementerian Pertanian menunjukkan produktivitas kopi Gayo sangat rendah, bahkan tidak mencapai 1 ton ha ${ }^{-1}$ dalam kurun waktu 3 tahun terakhir (Gambar 1) 


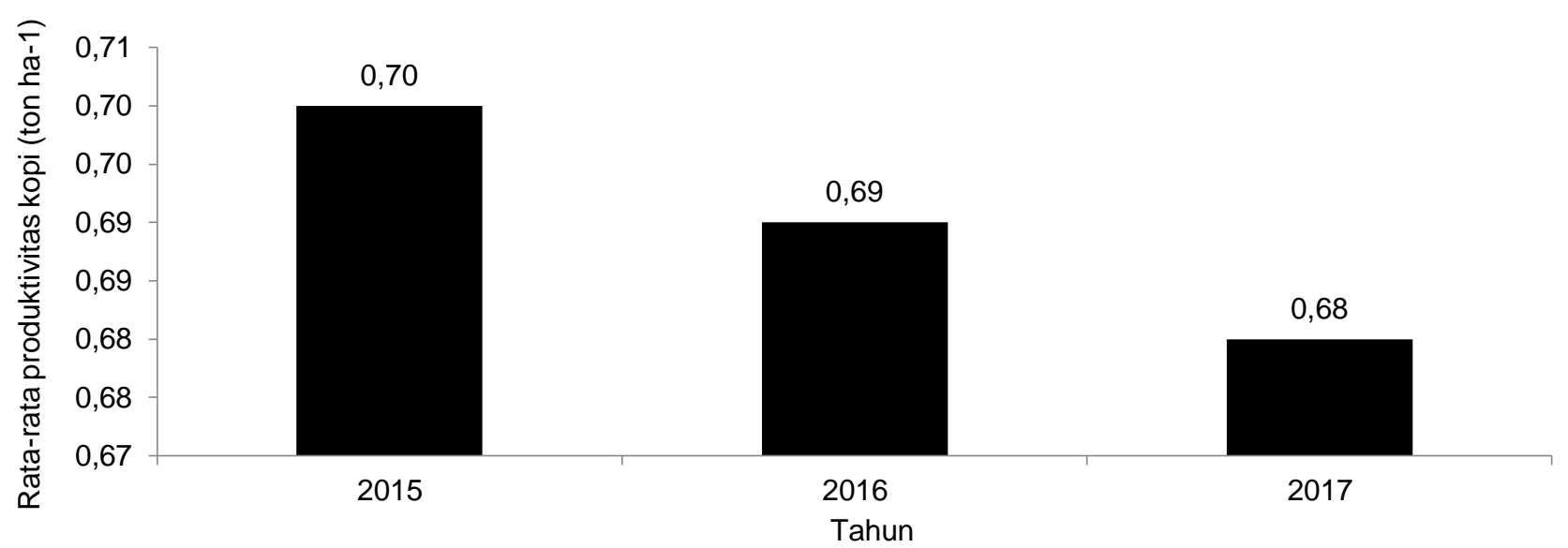

Gambar 1 Produktivitas kopi Arabika Gayo dari tahun 2015-2017 (Dirjenbun 2017).

Produktivitas kopi Arabika Gayo pada saat ini berkisar $650-750 \mathrm{~kg} \mathrm{ha}^{-1}$, yang masih jauh dari potensi hasil dari beberapa varietas yang ada saat ini yang mencapai 1,5-2 ton ha-1 (Jaya et al. 2011; 2014). Hal ini menunjukkan adanya selisih sekitar $850-1.250 \mathrm{~kg}$ ha $^{-1}$ antara produktivitas Arabika Gayo di tingkat petani dengan potensi produktivitas kopi Arabika Gayo. Produktivitas kopi Arabika Gayo yang rendah secara teknis disebabkan oleh banyaknya tanaman yang sudah tua atau tidak produktif ( $>30$ tahun), kejenuhan lahan karena dibudidayakan secara terus menerus, serangan hama dan penyakit tanaman yang tinggi intensitasnya, sistem budi daya yang tidak dilakukan secara maksimal (pemangkasan produksi), perubahan iklim global yang menyebabkan peningkatan suhu ratarata di dataran tinggi Gayo dan adanya mandatory dari konsumen atas produk organik, yang berpengaruh pada produktivitas akibat level kesuburan lahan dan serangan hama dan penyakit tanaman (Dishutbun Bener Meriah 2015). Upaya-upaya perbaikan terus dilakukan untuk menurunkan selisih yang tinggi antara kopi Arabika Gayo dengan potensi hasil tanaman dengan rekayasa teknologi budi daya melalui peremajaan tanaman, pemangkasan cabang produktif, penanaman dan pemangkasan naungan, pengendalian hama penyakit, dan pemupukan untuk mengganti unsur hara yang hilang bersama hasil tanaman.

Merujuk ke berbagai aspek peningkatan produksi kopi Gayo, yang menjadi salah satu aspek penting dalam budi daya kopi Gayo adalah upaya meningkatkan dan mempertahankan hasil secara berkesinambungan dengan perbaikan kesuburan tanah melalui pemupukan tanaman dengan pupuk organik yang mengandung unsur hara kompleks dan mampu memperbaiki tingkat kesuburan lahan serta ramah lingkungan. Penambahan bahan organik tanah dapat dilakukan dengan aplikasi pupuk organik, seperti pupuk organik cair (biourine) dan organik padat (biokompos). Dharmayanti et al. (2013) menyatakan bahwa biourine merupakan salah satu alternatif untuk meningkatkan ketersediaan, kecukupan, dan efisiensi serapan hara yang mengandung mikroorganisme sehingga dapat mengurangi penggunaan pupuk anorganik.

Biourine dan biokompos memiliki berbagai jenis berdasarkan pada bahan baku yang digunakan untuk memproduksi pupuk organik. Pemanfaatan bahan baku lokal yang tersedia sebagai bahan pembuatan biourine dan biokompos sangat mendukung upaya budi daya tanaman sistem zero waste farming system. Biourine yang digunakan berasal dari bioindustri perumahan petani kopi Gayo yang mengintegrasikan budi daya kopi Gayo dengan teknak sapi sehingga urine sapi dapat dimanfaatkan sebagai pupuk biourine. Wati et al. (2014) menyatakan bahwa biourine sapi merupakan bahan organik penambah kesuburan tanah yang berasal dari hasil fermentasi anaerobik urine dan feses sapi yang masih segar. Rianto et al. (2015) menyatakan bahwa biourine merupakan bahan organik hasil fermentasi sehingga memiliki kandungan unsur hara, enzim, dan hormon yang sangat dibutuhkan oleh tanaman. Dekomposisi bahan organik dari biourine sapi dapat memberikan tambahan unsur hara $\mathrm{N}, \mathrm{P}, \mathrm{K}$, dan hormon auksin yang dibutuhkan tanaman.

Biokompos merupakan hasil fermentasi bagian/ sisa-sisa tanaman yang mengandung unsur hara kompleks sesuai dengan kandungan hara pada bagian tanaman yang dijadikan sebagai bahan baku biokompos. Biokompos yang digunakan adalah limbah kulit kopi Gayo sisa hasil panen yang terbuang pada saat pengupasan green bean kopi. Pemanfaatan kulit kopi Gayo merupakan upaya penggunaan sumber daya lokal sebagai sumber bahan baku pupuk untuk memenuhi kebutuhan unsur hara tanaman. Hasil penelitian Baon et al. (2005) menunjukkan bahwa kadar C-organik kulit buah kopi sebesar 45,3\%, kadar nitrogen $2,98 \%$, fosfor $0,18 \%$, dan kalium $2,26 \%$.

Penelitian Simanjuntak et al. (2013) menunjukkan bahwa aplikasi kompos kulit kopi pada tanaman bawang merah mampu meningkatkan kadar C-organik tanah dibandingkan dengan aplikasi pupuk N, P, dan K. Penggunaan pupuk kompos pada dasarnya sangat mendukung peningkatan produksi dan perbaikan lahan, tetapi sangat lambat dalam dekomposisi unsur hara menjadi unsur hara yang tersedia bagi tanaman. 
Hasil penelitian Falahudin et al. (2016) menunjukkan bahwa penambahan pupuk organik limbah kulit kopi $400 \mathrm{~g}$ (P4) memberikan efek yang nyata pada pertumbuhan tinggi tanaman dan lebar daun sehingga pupuk organik limbah kulit kopi $400 \mathrm{~g}$ memberikan pertumbuhan maksimum pada tanaman kopi. Kombinasi pemupukan biourine dan bikompos merupakan upaya untuk meningkatkan produktivitas kopi Arabika Gayo dari $600-750 \mathrm{~kg} \mathrm{ha}^{-1}$ menjadi lebih tinggi sehingga dapat menurunkan selisih produksi tingkat petani pada saat ini dengan potensi hasil tanaman kopi Arabika Gayo yang mencapai 850-1250 kg ha-1.

Berdasarkan upaya-upaya perbaikan produktivitas kopi Arabika Gayo maka penelitian ini bertujuan untuk mengevaluasi pengaruh aplikasi berbagai dosis pemupukan biourine dan biokompos pada peningkatan produktivitas kopi Arabika Gayo I dan Gayo II.

\section{METODE PENELITIAN}

Penelitian ini dilaksanakan pada bulan AprilSeptember 2018 di Kebun Percobaan (KP) Gayo, Bener Meriah, Aceh. Analisis tanah dilakukan di Laboratorium Tanah dan Tanaman Balai Pengkajian Teknologi Pertanian (BPTP) Aceh, Banda Aceh, Aceh.

Bahan dan alat yang digunakan ialah varietas kopi Arabika Gayo I dan Gayo II, biourine, biokompos, dan NPK mutiara, gembor, cangkul, ring sampel, kored, meteran, timbangan analitik, timbangan kasar, sprayer, tali rafia, plastik, label, dan jangka sorong. Tanaman kopi Arabika Gayo yang digunakan sebagai bahan penelitian adalah Arabika Gayo I berumur 7 tahun dan Arabika Gayo II berumur 4 tahun dengan luasan secara keseluruhan 1 ha. Jarak tanam kopi Arabika Gayo adalah 2,5 x 2,5 m dan naungan (Lamtoro) $5 \times 5 \mathrm{~m}$ sehingga terdapat 1.600 pupulasi kopi Arabika Gayo. Kopi Arabika Gayo I memiliki warna daun hijau tua, buah berbentuk agak memanjang dan ujung agak tumpul, masak buah kurang serempak, warna buah hijau bersih pada saat muda dan berwarna merah cerah pada saat masak, potensi hasil rata-rata $0,9-1,2$ ton ha ${ }^{-1}$ biji kering, toleran terhadap penyakit karat daun, dan memiliki cita rasa yang baik. Kopi Arabika Gayo II memiliki warna daun hijau tua dengan pupus berwarna cokelat kemerahan, buah berbentuk oval, dompolan buah agak rapat, warna buah hijau bersih pada saat muda dan berwarna merah cerah pada saat masak, potensi hasil rata-rata $0,9-1,1$ ton $\mathrm{ha}^{-1}$ biji kering, agak tahan terhadap penyakit karat daun, dan cita rasa yang sangat baik (BPTP Aceh 2010).

Rancangan penelitian menggunakan rancangan petak terpisah (RPT) pola faktorial yang terdiri atas varietas (A) sebagai petak utama dan paket pemupukan (C) sebagai anak petak dengan paket pemupukan berbagai dosis biourine dan biokompos serta pupuk dasar NPK $100 \mathrm{~kg} \mathrm{ha}^{-1}$. Petak utama terdiri atas 2 varietas, yaitu kopi Arabika Gayo 1 (A1) dan Gayo II (A2) dan paket pemupukan yang terdiri atas paket NPK $150 \mathrm{~kg} \mathrm{ha}^{-1}$ (perlakuan petani/kontrol) (C1),
$150 \mathrm{~mL}$ plant $^{1}$ (biourine) +5 ton ha $^{-1}$ (biokompos) + NPK $100 \mathrm{~kg} \mathrm{ha}^{-1}$ (C2), $125 \mathrm{~mL}$ plant $^{-1}$ (biourine) $+7,5$ ton ha-1 (biokompos) + NPK $100 \mathrm{~kg} \mathrm{ha}^{-1}$ (C3), dan 100 $\mathrm{mL}$ plant $^{-1}$ (biourine) +10 ton ha $^{-1}$ (biokompos) + NPK $100 \mathrm{~kg} \mathrm{ha}^{-1}$ (C4) sehingga kombinasi 2 petak utama dan 4 anak menghasilkan 8 kombinasi perlakuan yang diulang sebanyak 3 kali sehingga menghasilkan 24 unit percobaan, dengan sampel pengamatan sebanyak 6 tanaman per unit percobaan. Aplikasi pemupukan NPK dilakukan pada fase vegetatif, biourine diaplikasi 2 kali pada fase vegetatif dan menjelang pembungaan kopi, dan biokompos diaplikasikan pada awal penelitian. Aplikasi perlakuan dilakukan setelah pengambilan sampel tanah untuk mengetahui kandungan unsur hara di lokasi penelitian.

Pengamatan vegetatif tanaman dilakukan 2 kali selama penelitian, yaitu pada awal perlakuan (April 2018) sebagai data awal dan bulan Agustus 2018. Pengamatan vegetatif, yaitu tinggi $(\mathrm{cm})$ dan jumlah cabang (cabang) untuk melihat perubahan variabel pengamatan sebelum dan sesudah aplikasi perlakuan. Pengamatan generatif dilakukan 1 kali pada saat panen (Agustus-September 2018) berupa jumlah dompol per cabang (dompol), jumlah buah per dompol (buah), dan produktivitas (ton ha-1).

Hasil pengamatan dilakukan analisis sidik ragam (ANOVA) 95\%, jika F hitung lebih besar daripada $F$ tabel maka dilanjutkan dengan Uji Jarak Berganda Duncan (UJBD) 95\%. Selain itu, dilakukan analisis regresi atas dosis pupuk biourine dan biokompos dengan rata-rata produktivitas kopi Arabika Gayo untuk mengetahui hubungan sebab akibat dosis pupuk dengan peningkatan produktivitas kopi Arabika Gayo.

\section{HASIL DAN PEMBAHASAN}

\section{Kondisi Umum Lokasi Penelitian}

Budi daya kopi Arabika Gayo di lokasi penelitian menerapkan teknis budi daya secara optimal melalui pemangkasan tanaman kopi dan naungan, pengendalian gulma, hama, dan penyakit tanaman secara terus menerus selama penelitian sampai panen. Teknis budi daya yang tepat harus didukung oleh tingkat ketersedian unsur hara sehingga dilakukan analisis tanah untuk mengetahui kandungan unsur hara sebelum dilakukan aplikasi berbagai dosis pemupukan pada varietas kopi Arabika Gayo I dan Gayo II. Analisis tanah meliputi pH tanah, C-organik, Ntotal, $\mathrm{C} / \mathrm{N}, \mathrm{P}_{2} \mathrm{O}_{5}$, dan $\mathrm{K}_{2} \mathrm{O}$.

Berdasarkan Tabel 1, dapat dilihat bahwa $\mathrm{pH}$ tanah tergolong masam (rendah) yang berkisar antara 4,785,39, C-organik tinggi sebesar $4,21-4,82 \%, \mathrm{C} / \mathrm{N}$ sebesar $10,98-15,48, \mathrm{~N}$ total sebesar $0,34-0,43 \%, \mathrm{P}_{2} \mathrm{O}_{5}$ sebesar 12,03-20,97 mg $100 \mathrm{~g} \mathrm{~g}^{-1}$, dan $\mathrm{K}_{2} \mathrm{O}$ sebesar $55,52-61,40 \mathrm{mg} 100 \mathrm{~g}^{-1}$ pada semua perlakuan. Jumlah hara yang tersedia dalam tanah belum tentu tersedia untuk tanaman karena dipengaruhi oleh berbagai faktor, antara lain unsur hara tanah terikat oleh partikel tanah dan unsur hara yang lain, kemampuan akar 
Tabel 1 Rata-rata kandungan hara dalam tanah sebelum perlakuan pemupukan pada kedalaman 0-20 dan 20-40 cm

\begin{tabular}{|c|c|c|c|c|c|c|}
\hline \multirow{3}{*}{ Perlakuan } & \multicolumn{6}{|c|}{ Unsur hara } \\
\hline & \multirow{2}{*}{$\begin{array}{c}\mathrm{pH} \\
\mathrm{H} 2 \mathrm{O}\end{array}$} & C-organik & N-Total & \multirow{2}{*}{$\mathrm{C} / \mathrm{N}$} & $\mathrm{P}_{2} \mathrm{O}_{5}$ & $\mathrm{~K}_{2} \mathrm{O}$ \\
\hline & & \multicolumn{2}{|c|}{$\%$} & & \multicolumn{2}{|c|}{$\mathrm{mg} / 100 \mathrm{~g}$} \\
\hline $\mathrm{A} 1 \mathrm{C} 1$ & 5,19 & 4,36 & 0,36 & 12,31 & 20,97 & 54,66 \\
\hline $\mathrm{A} 1 \mathrm{C} 2$ & 5,08 & 4,43 & 0,37 & 11,80 & 14,83 & 53,66 \\
\hline A1C3 & 4,78 & 4,40 & 0,41 & 10,98 & 16,36 & 61,40 \\
\hline A1C4 & 5,16 & 4,82 & 0,43 & 11,43 & 16,05 & 60,11 \\
\hline $\mathrm{A} 2 \mathrm{C} 1$ & 5,33 & 4,29 & 0,38 & 11,45 & 14,23 & 55,52 \\
\hline $\mathrm{A} 2 \mathrm{C} 2$ & 5,39 & 4,22 & 0,34 & 13,05 & 12,03 & 55,81 \\
\hline $\mathrm{A} 2 \mathrm{C} 3$ & 5,33 & 4,46 & 0,36 & 15,48 & 14,19 & 55,67 \\
\hline $\mathrm{A} 2 \mathrm{C} 4$ & 5,26 & 4,21 & 0,38 & 11,67 & 13,02 & 58,25 \\
\hline \multicolumn{7}{|c|}{ Mandiri pemupukan } \\
\hline C1 & 5,26 & 4,33 & 0,37 & 11,88 & 17,60 & 55,09 \\
\hline $\mathrm{C} 2$ & 5,23 & 4,32 & 0,36 & 12,43 & 13,43 & 54,73 \\
\hline C3 & 5.05 & 4,43 & 0.38 & 13,23 & 15,28 & 58.53 \\
\hline C4 & 5,21 & 4,51 & 0,40 & 11,55 & 14,53 & 59,18 \\
\hline
\end{tabular}

Keterangan: *Hasil analisis laboratorium tanah dan tanaman BPTP Aceh 2018.

tanaman dalam menyerap unsur hara, dan ketersediaan air tanah. Penggunaan pupuk anorganik secara terus menerus dengan dosis yang tinggi secara perlahan mengakibatkan degradasi lahan. Putro et al. (2016) menyatakan bahwa pemupukan yang berlebih dapat menyebabkan penurunan kesuburan tanah (penurunan nilai $\mathrm{N}, \mathrm{P}$, dan $\mathrm{K}$ pada tanah). Aribawa (2008) menyatakan bahwa pemberian pupuk organik dapat meningkatkan daya larut unsur $\mathrm{P}, \mathrm{K}, \mathrm{Ca}$, dan Mg, meningkatkan C-organik, kapasitas tukar kation, daya serap air, menurunkan kejenuhan Al dan bulk density (BD) tanah. Hasil penelitian Valentiah et al. (2015) memunjukkan bahwa penggunaan pupuk dari kulit biji kopi mampu meningkatkan ketersedian C-organik tanah, meningkatkan $\mathrm{pH}$ tanah, ketersedian Nitrogen $(\mathrm{N})$, Fosfor $(\mathrm{P})$, dan kalium $(\mathrm{K})$ dengan dosis pupuk 30 ton ha-1.

\section{Pertumbuhan Vegetatif dan Generatif Tanaman}

Hasil analisis sidik ragam menunjukkan bahwa tidak terjadi ineteraksi paket teknologi pemupukan dengan varietas kopi Arabika Gayo I dan Gayo II pada variabel pertumbuhan vegetatif dan generatif tanaman, tetapi perlakuan mandiri dosis pemupukan berpengaruh pada produktivitas tanaman, sedangkan perlakuan mandiri varietas berpengaruh pada variabel tinggi tanaman, jumlah cabang, dan jumlah dompol per cabang (Tabel 2).

Kombinasi perlakuan pemupukan dan varietas tidak berpengaruh nyata pada variabel vegetatif kopi Arabika Gayo I dan Gayo II karena pupuk biokompos membutuhkan waktu yang lama untuk proses dekomposisi menjadi unsur hara yang tersedia bagi tanaman kopi Arabika Gayo. Fungsi biourine dan biokompos pada penelitian ini tidak berpengaruh nyata pada semua parameter vegetatif tanaman kopi karena tanaman dapat menyerap unsur hara dari pupuk NPK yang diberikan sebagai sumber nutrisi pada awal pertumbuhan, walaupun pada dasarnya biourine memiliki peran yang lebih optimal pada pertumbuhan vegetatif dibandingkan dengan pada fase generatif, tetapi umur kopi Arabika Gayo yang lama (tahunan) dan penggunaan pupuk NPK mengakibatkan fungsi biourine belum terlihat secara nyata. Dharmayanti et al. (2013) menjelaskan bahwa pemberian biourine mampu menambah hara tanah, seperti K- tersedia dan $\mathrm{N}$-total dalam tanah. Hasil uji UJBD 95\% menunjukkan bahwa perlakuan varietas berbeda nyata pada tinggi tanaman, cabang produktif, dan jumlah dompol per cabang.

Berdasarkan Tabel 3 dapat dilihat bahwa perlakuan mandiri biourine $100 \mathrm{~mL}^{\text {plant }}{ }^{1}+$ biokompos 10 ton ha 1 + NPK $100 \mathrm{~kg} \mathrm{ha}^{-1}$ (C4) menunjukkan produktivitas kopi Arabika Gayo terbaik, yang berbeda nyata dibandingkan dengan perlakuan NPK $100 \mathrm{~kg} \mathrm{ha}^{-1}$ tanpa biourine dan biokompos (C1) dan perlakuan biourine $150 \mathrm{~mL}$ plant $^{-1}$ + biokompos 5 ton ha ${ }^{-1}+$ NPK $100 \mathrm{~kg}$ ha $^{-1}$ (C2), tetapi tidak berbeda nyata dibandingkan dengan perlakuan biourine $125 \mathrm{~mL}$ plant $^{-1}+7,5$ ton ha 1 + NPK $100 \mathrm{~kg} \mathrm{ha}^{-1}$ (C3). Perlakuan mandiri varietas Arabika Gayo II (A2) menunjukkan tinggi tanaman dan jumlah cabang terbaik yang berbeda nyata dibandingkan dengan varietas Arabika Gayo I (A1), sedangkan pada variabel jumlah dompol per cabang varietas Arabika Gayo I (A1) menunjukkan jumlah dompol cabang terbanyak yang berbeda nyata dibandingkan dengan varietas Arabika Gayo II (A2) (Tabel 3).

\section{Tinggi dan Jumlah Cabang Tanaman}

Berdasarkan hasil uji beda menunjukkan bahwa perlakuan varietas kopi Arabika Gayo berbeda nyata dalam tinggi tanaman, dengan hasil kopi Arabika Gayo II yang memiliki tinggi yang lebih baik dari Gayo I. Hal ini diduga karena adanya perbedaan umur tanaman kopi Arabika Gayo I dan Gayo II yang dijadikan bahan penelitian ini sehingga memiliki tinggi yang berbeda pada awal pengamatan. Pada tanaman kopi Arabika Gayo I dengan pertumbuhan vegetatif yang normal pada umur 7 tahun perlu dilakukan pemangkasan tanaman untuk memaksimalkan produksi tanaman karena pertumbuhan vegetatif yang dominan akan menurunkan produksi tanaman sehingga pemangkasan bertujuan untuk mengurangi dominasi partumbuhan vegetatif tanaman. Kopi Gayo dengan umur 7 tahun telah mencapai pertumbuhan vegetatif yang 
Tabel 2 Hasil analisis ANOVA pengaruh perlakuan pada variabel pengamatan tanaman kopi Arabika Gayo I dan Gayo II

\begin{tabular}{|c|c|c|c|c|}
\hline \multirow{2}{*}{ Variabel Pengamatan } & \multicolumn{4}{|c|}{ Perlakuan } \\
\hline & Pupuk & Varietas & Interaksi & Taraf kepercayaan \\
\hline Tinggi tanaman $(\mathrm{cm})$ & $\operatorname{tn}$ & ** & th & \\
\hline Jumlah cabang (cabang) & tn & ** & tn & \\
\hline Jumlah dompol per cabang (dompol) & tn & * & tn & $95 \%$ \\
\hline Jumlah buah per dompol (buah) & tn & tn & tn & \\
\hline Produktivitas (ton ha-1) & * & tn & tn & \\
\hline
\end{tabular}

Tabel 3 Hasil analisis sidik ragam dan uji lanjut perlakuan pemupukan pada kopi Arabika Gayo I dan Gayo II

\begin{tabular}{|c|c|c|c|c|c|}
\hline \multirow[b]{2}{*}{ Perlakuan } & \multicolumn{5}{|c|}{ Hasil analsis sidik ragam dan uji beda perlakuan } \\
\hline & $\begin{array}{c}\text { Tinggi } \\
\text { tanaman }(\mathrm{cm})\end{array}$ & $\begin{array}{c}\text { Jumlah } \\
\text { cabang (cabang) }\end{array}$ & $\begin{array}{l}\text { Jumlah dompol } \\
\text { per cabang } \\
\text { (dompol) }\end{array}$ & $\begin{array}{l}\text { Jumlah buah per } \\
\text { dompol (buah) }\end{array}$ & $\begin{array}{l}\text { Produktivitas } \\
\text { (ton ha-1) }\end{array}$ \\
\hline $\mathrm{A} 1$ & $157,38^{b}$ & $7,75^{b}$ & $38,00^{a}$ & 11,75 & 1,42 \\
\hline A2 & $166,5^{\mathrm{a}}$ & $17,96^{\text {a }}$ & $18,25^{\mathrm{b}}$ & 12,58 & 1,67 \\
\hline UJBD 95\% & * & ** & * & tn & tn \\
\hline C1 & 164,08 & 11,25 & 24,67 & 11,83 & $1,20^{\mathrm{b}}$ \\
\hline $\mathrm{C} 2$ & 162,00 & 12,25 & 25,17 & 12,17 & $1,29^{b}$ \\
\hline C3 & 159,42 & 13,50 & 29,58 & 12,67 & $1,67^{\mathrm{ab}}$ \\
\hline $\mathrm{C} 4$ & 162,25 & 14,42 & 33,08 & 12,00 & $2,03^{a}$ \\
\hline UJBD95\% & tn & tn & tn & tn & * \\
\hline
\end{tabular}

Keterangan: Bilangan yang didampingi huruf yang berbeda pada kolom yang sama dengan perlakuan yang berbeda menunjukkan berbeda nyata berdasarkan uji UJBD 95\%; tn = tidak berpengaruh nyata, * = berpengaruh nyata, dan ${ }^{* *}=$ berpengaruh sangat nyata berdasarkan hasil analisis sidik ragam.

optimal sehingga pertambahan tinggi, diameter batang, dan cabang primer menjadi sangat lambat/ rendah.

Pemangkasan dilakukan untuk mengatur pertumbuhan vegetatif ke pertumbuhan generatif yang produktif, mempermudah pemanenan dengan mengatur tinggi tanaman, pembentukan cabang-cabang produktif baru dan mengatur penyinaran dalam tanaman kopi sehingga tinggi tanaman berkurang atau menurun bersamaan dengan pemangkasan tanaman pada kopi Arabika Gayo I. Pemangkasan kopi dilakukan dengan pemangkasan bentuk untuk menjaga tanaman tidak terlalu tinggi, pemangkasan produktif untuk menumbuhkan cabang-cabang produktif dalam jumlah yang cukup dan pemangkasan rejuvenasi untuk meremajakan tanaman kopi yang sudah tua (Atrisiandy 2015). Selain itu, pemangkasan dilakukan untuk mempermudah proses pemanenan hasil tanaman kopi karena tinggi tanaman menjadi ideal dengan tinggi pemanen (Panggabean 2011).

Pada jumlah cabang produktif tanaman menunjukkan bahwa varietas Gayo II memiliki jumlah yang lebih banyak dibandingkan dengan Gayo I yang masing-masing dengan rata-rata 17,96 batang dan 7,75 batang. Hal ini terjadi karena pada Arabika Gayo II, cabang-cabang yang terbentuk berupa cabang primer yang menjadi cabang produktif tanaman, sedangkan pada Arabika Gayo I, telah dilakukan pemangkasan cabang primer karena telah berkembang cabang-cabang sekunder dan tersier pada cabang primer untuk mempertahankan hasil dan keseimbangan tanaman. Hal ini dapat terlihat pada jumlah dompol per cabang, di mana Arabika Gayo I memiliki jumlah yang lebih banyak dengan rata-rata 38,00 dari kopi Gayo II yang rata-rata 18,25 dompol karena dompolan buah banyak bermunculan pada cabang sekunder dan tersier pada kopi Gayo I.

\section{Produktivitas Tanaman}

Kombinasi perlakuan pemupukan dan varietas tidak berpengaruh pada produktivitas kopi Arabika Gayo sehingga tidak terjadi interaksi antara pemupukan dan varietas tanaman. Rata-rata produktivitas pada Gayo I dan II dengan aplikasi pemupukan biourine dan biokompos menunjukkan bahwa kombinasi aplikasi dosis pemupukan dan varietas tanaman tidak berpengaruh pada produktivitas tanaman. Perlakuan varietas Arabika Gayo I (A1) menunjukkan nilai tertinggi pada dosis $125 \mathrm{~mL}$ plant $^{-1}$ (biourine) + 7,5 ton ha ${ }^{-1}$ (biokompos) + NPK $100 \mathrm{~kg} \mathrm{ha}^{-1}$ (C3) dan terendah pada dosis NPK $150 \mathrm{~kg} \mathrm{ha}^{-1}$ (C1), sedangkan pada varietas Arabika Gayo II (A2) tertinggi pada dosis $100 \mathrm{~mL}$ plant ${ }^{1}$ (biourine) +10 ton ha-1 ${ }^{-1}$ biokompos) + NPK $100 \mathrm{~kg} \mathrm{ha}^{-}$ 1 (C4) dan terendah pada dosis NPK $150 \mathrm{~kg} \mathrm{ha}^{-1}$ (C1) sehingga tidak terjadi interaksi antara aplikasi berbagai dosis pemupukan pada produktivitas Arabika Gayo I dan Gayo II (Gambar 2).

Kombinasi dosis biourien dan biokompos dengan varietas kopi Arabika Gayo I dan Gayo II tidak berinteraksi, tetapi perlakuan dosis biourien dan biokompos (mandiri) berpengaruh nyata pada rata-rata produktivitas kopi Arabika Gayo. Perubahan dosis pemupukan berkolerasi positif dengan perubahan ratarata produktivitas kopi Arabika Gayo.

Berdasarkan Gambar 3 dapat dilihat bahwa pemupukan biourine $100 \mathrm{~mL}$ plant $^{-1}+$ biokompos 10 ton ha-1 + NPK $100 \mathrm{~kg} \mathrm{ha}^{-1}$ (C4) memiliki rata-rata produktivitas tertinggi sebesar 2,03 ton ha-1 yang berbeda nyata dibandingkan dengan pemupukan NPK $150 \mathrm{~kg} \mathrm{ha}^{-1}$ tanpa biourine dan biokompos (C1), yaitu 


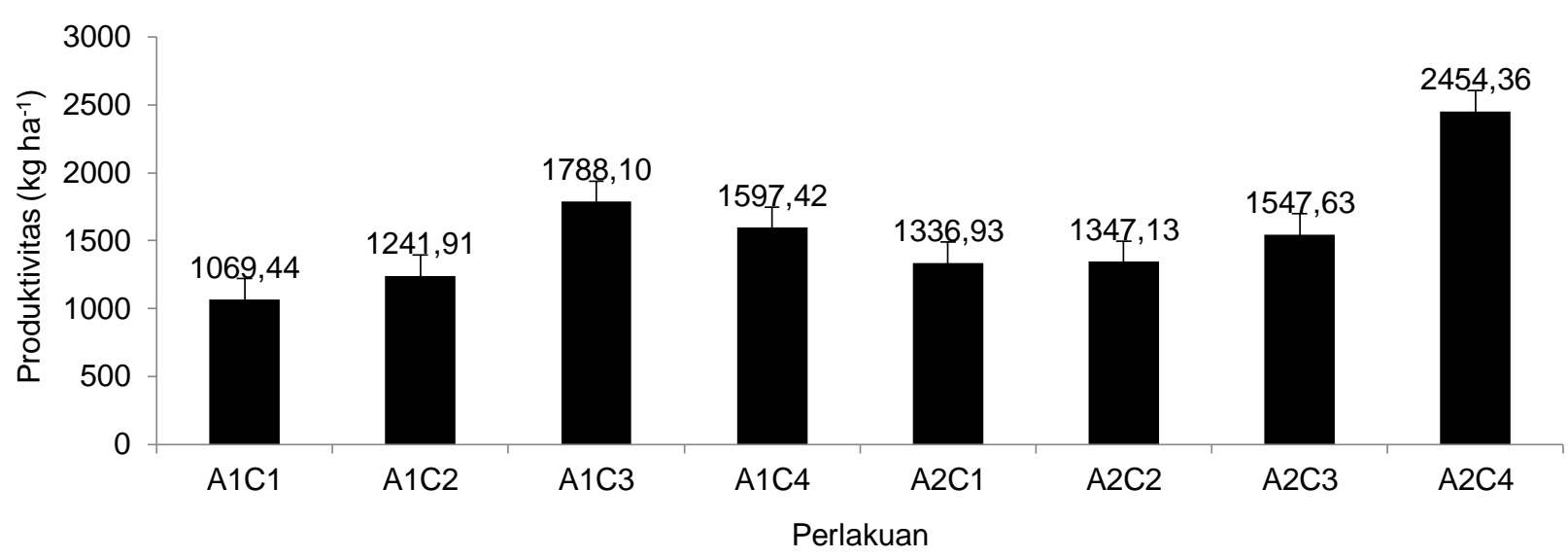

Gambar 2 Rata-rata produktivitas kopi Gayo I dan II dengan aplikasi biourine dan biokompos. A1C1 = Arabika Gayo 1 dengan paket NPK $150 \mathrm{~kg} \mathrm{ha}^{-1} ; \mathrm{A} 1 \mathrm{C} 2=$ Arabika Gayo 1 dengan $150 \mathrm{~mL}^{\text {plant }}{ }^{-1}$ (biourine) +5 ton ha $^{-1}$ (biokompos) + NPK $100 \mathrm{~kg} \mathrm{ha}^{-1} ; \mathrm{A} 1 \mathrm{C3}=$ Arabika Gayo 1 dengan $125 \mathrm{~mL}^{\text {plant }}{ }^{-1}$ (biourine) + 7,5 ton ha ${ }^{-1}$ (biokompos) + NPK $100 \mathrm{~kg}$ ha $^{-1}$; A1C4 = Arabika Gayo 1 dengan $100 \mathrm{~mL}_{\text {plant }}{ }^{1}$ (biourine) +10 ton ha $^{-1}$ (biokompos) + NPK $100 \mathrm{~kg} \mathrm{ha}^{-1} ; \mathrm{A}_{2 \mathrm{C}}$ $=$ Arabika Gayo II dengan paket NPK $150 \mathrm{~kg} \mathrm{ha}^{-1} ; \mathrm{A} 2 \mathrm{C} 2$ = Arabika Gayo II dengan $150 \mathrm{~mL}^{\text {plant }}{ }^{-1}$ (biourine) +5 ton ha ${ }^{-1}$ (biokompos) + NPK $100 \mathrm{~kg} \mathrm{ha}^{-1}$; A2C3 = Arabika Gayo II dengan $125 \mathrm{~mL}^{\text {plant }}{ }^{-1}$ (biourine) $+7,5$ ton ha $^{-1}$ (biokompos) + NPK $100 \mathrm{~kg} \mathrm{ha}^{-1}$; dan A2C4 = Arabika Gayo II dengan $100 \mathrm{~mL}^{\text {plant }}{ }^{-1}$ (biourine) +10 ton ha $^{-1}$ (biokompos) + NPK $100 \mathrm{~kg} \mathrm{ha}^{-1}$.

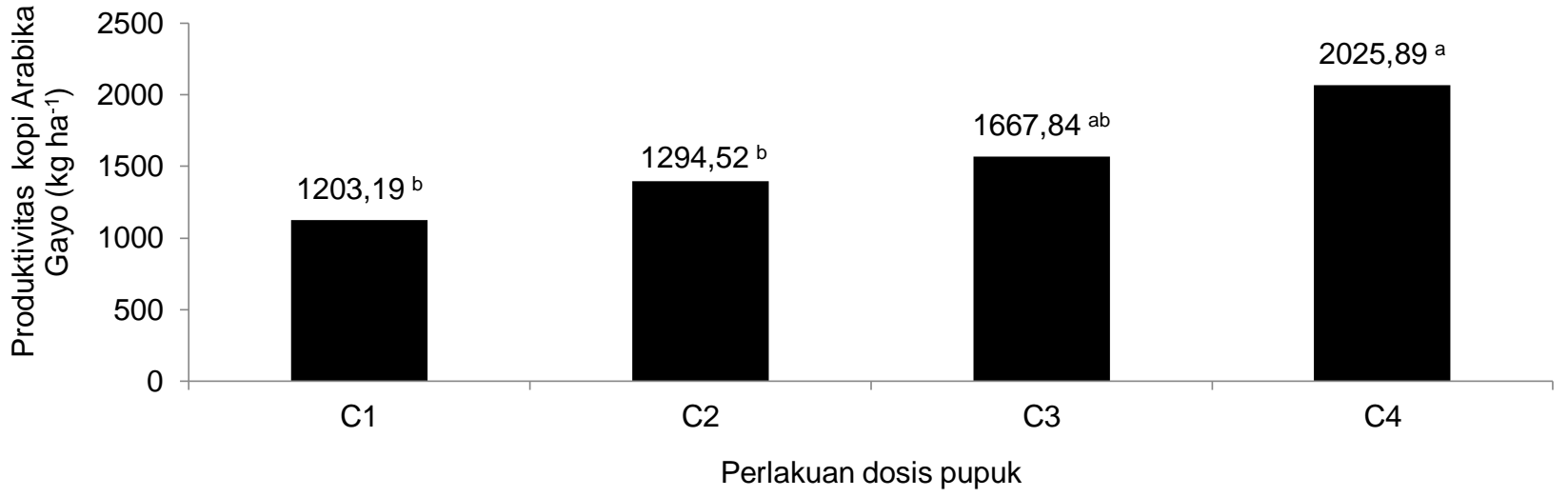

Gambar 3 Rata-rata produktivitas kopi Arabika Gayo dengan berbagai aplikasi dosis pemupukan biourine dan biokompos. $\mathrm{C} 1$ = Paket NPK $150 \mathrm{~kg} \mathrm{ha}^{-1} ; \mathrm{C} 2=$ Paket $150 \mathrm{~mL}^{\text {plant }}{ }^{-1}$ (biourine) +5 ton ha-1 (biokompos) + NPK $100 \mathrm{~kg} \mathrm{ha}^{-1} ; \mathrm{C}^{-1}$ $=125 \mathrm{~mL}_{\text {plant }}{ }^{-1}$ (biourine) $+7,5$ ton ha $^{-1}$ (biokompos) $+\mathrm{NPK} 100 \mathrm{~kg} \mathrm{ha}^{-1} ;$ dan $\mathrm{C} 4=100 \mathrm{~mL}_{\text {plant }}{ }^{-1}$ (biourine $)+10$ ton ha-1 (biokompos) + NPK $100 \mathrm{~kg} \mathrm{ha}^{-1}$.

sebesar 1,20 ton ha-1. Hal ini menunjukkan bahwa aplikasi biourine dan biokompos dapat memenuhi kebutuhan unsur hara dan perbaikan perakaran tanaman sehingga menghasilkan produksi yang lebih tinggi dibandingkan dengan tanpa aplikasi biourine dan biokompos, bahkan peningkatan dosis biokompos berbanding lurus dengan peningkatan produksi kopi Arabika Gayo. Hasil penelitian Anggara et al. (2016) menunjukkan bahwa perlakuan pupuk biourine dengan konsentrasi tertinggi $1.725 \mathrm{~L} \mathrm{ha}^{-1}$ dengan kombinasi pupuk anorganik dosis $100 \mathrm{~kg} \mathrm{~N} \mathrm{ha}^{-1}, 300 \mathrm{~kg} \mathrm{P}_{2} \mathrm{O}_{5} \mathrm{ha}^{-}$ $1,100 \mathrm{~kg} \mathrm{~K}_{2} \mathrm{O}$ ha $^{-1}$ memberikan pertumbuhan jumlah daun dan jumlah cabang yang lebih baik, tetapi tidak berpengaruh pada hasil tanaman buncis secara keseluruhan.

Peningkatan dosis biokompos mampu menyediakan kebutuhan hara tanaman melalui perakaran dalam jangka waktu yang lama untuk mendukung peningkatan produktivitas tanaman. Hasil penelitian
Effandi et al. (2014) menyatakan bahwa aplikasi biochar dan kompos mampu meningkatkan produktivitas sampai dua kali lipat, yaitu dari 20,43 t ha-1 menjadi 40,95 t ha ${ }^{-1}$ sehingga biochar dan kompos kulit kopi dengan dosis 10-20 ton ha-1 dianjurkan pada tanah Andisol. Sejalan dengan hasil yang dilaporkan oleh Simajuntak et al. (2013) yang menunjukkan bahwa kompos kulit buah kopi berpengaruh nyata pada produksi per plot bawang merah, dengan kompos dosis 10 ton ha ${ }^{-1}$ dapat meningkatkan produksi tanaman sebesar 10,26\% dibandingkan dengan tanpa pemberian kompos.

Hasil penelitian menunjukkan bahwa penggunaan pupuk organik memberikan pengaruh nyata pada produktivitas kopi Arabika Gayo sehingga dilakukan analisis regresi untuk mengetahui hubungan sebab akibat antara dosis biokompos dan produktivitas kopi Arabika Gayo. Analisis dilakukan untuk melihat hubungan biokompos tanpa melihat pengaruh biourine 
karena berdasarkan hasil penelitian menunjukkan bahwa produksi terbaik diperoleh pada aplikasi biourine dengan dosis $100 \mathrm{~mL}^{\text {plant }}{ }^{1}$ (C4), bukan pada dosis biourine tertinggi $150 \mathrm{~mL}^{\text {plant }}{ }^{1}$ (C2). Hal ini terjadi karena biourine memiliki peran optimal pada pertumbuhan vegetatif tanaman sehingga banyak dimanfaatkan pada tanaman sayur-sayuran yang memanfaatkan daun tanaman sebagai ukuran produksi tanaman. Pola integrasi pemupukan biourine dan biokompos merupakan pola pemupukan organik dengan pemanfaatan peran pupuk cair dan pupuk padat secara bersamaan. Biourine digunakan pada awal pertumbuhan sebagai penyedia unsur hara tanaman secara cepat selama masa vegetatif, sedangkan biokompos membutuhkan waktu yang lama untuk terdekomposisi menjadi unsur hara yang tersedia bagi tanaman yang dapat menjadi sumber unsur hara pada masa generatif.

Analisis regresi dilakukan untuk melihat hubungan antara berbagai dosis mandiri biokompos dan produktivitas kopi Arabika Gayo I. Hasil analisis regresi linear menunjukkan adanya hungan antara dosis pemupukan biokompos dan produksi kopi Arabika Gayo I karena peningkatan dosis biokompos berpengaruh $60 \%$ pada peningkatan produksi (Gambar 4).

Analisis regresi dilakukan untuk melihat hubungan antara berbagai dosis mandiri biokompos dengan produktivitas kopi Arabika Gayo II. Hasil analisis regresi kuadratik menunjukkan adanya hungan antara peningkatan dosis pemupukan biokompos dengan produktivitas kopi Arabika Gayo II karena peningkatan dosis biokompos berpengaruh $72 \%$ pada peningkatan produktivitas, tetapi pada peningkatan dosis 10 ton ha1 produktivitas tanaman menunjukkan penurunan (Gambar 5).

Analisis regresi yang dilakukan menunjukkan hubungan antara penggunaan pupuk biokompos dengan rata-rata produksi kopi Arabika Gayo. Bedasarkan Gambar 6 dapat dilihat bahwa dosis pupuk biokompos memiliki nilai $R^{2}=0,80$ yang artinya $80 \%$ peningkatan produksi kopi Arabika Gayo dipengaruhi oleh peningkatan dosis biokompos. Hal ini menunjukkan hubungan sebab akibat yang sangat kuat antara dosis biokompos dengan produksi tanaman, Hal ini sejalan dengan hasil analisis sidik ragam yang menunjukkan bahwa peningkatan dosis pupuk biokompos secara sifnifikan meningkatkan produktivitas tanaman (Gambar 3). Rumus regresi linear $y=77,435 x+1088,5$ yang berarti bahwa setiap peningkatan dosis biokompos sebesar 1 ton dapat meningkatkan hasil sebesar 77,435 kg. Berdasarkan hasil analisis regresi menunjukkan dengan pemupukan biokompos 7,5 ton $\mathrm{ha}^{-1}$ dapat mencapai hasil yang lebih tinggi dari yang diperoleh pada penelitian ini, yaitu $1669,46 \mathrm{~kg} \mathrm{ha}^{-1}$,

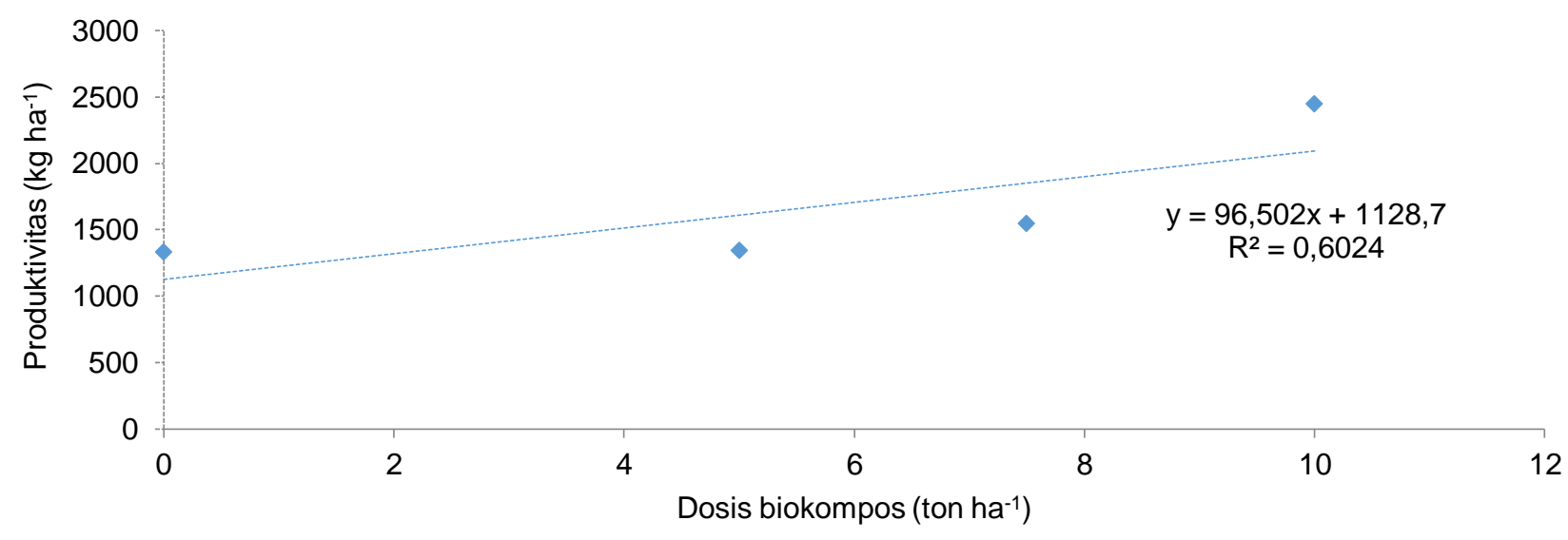

Gambar 4 Hasil analisis regresi linear pengaruh aplikasi biokompos pada rata-rata produktivitas kopi Arabika Gayo I.

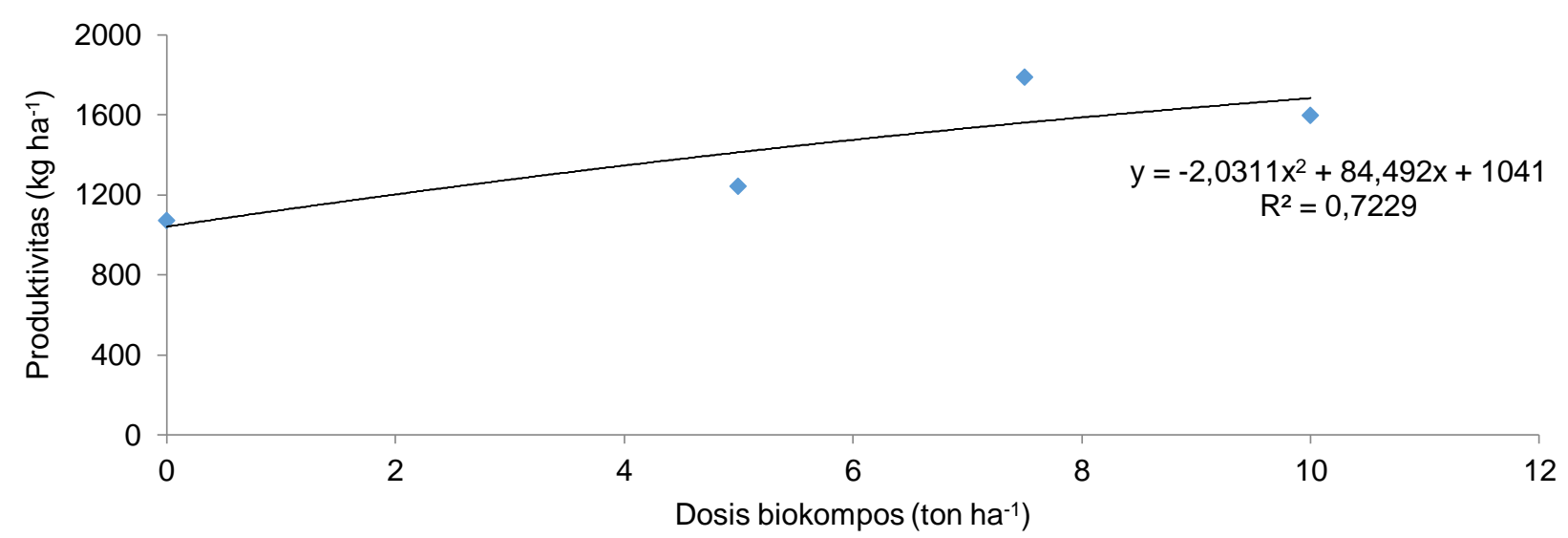

Gambar 5 Hasil analisis regresi kuadratik pengaruh aplikasi biokompos pada rata-rata produktivitas kopi Arabika Gayo II. 


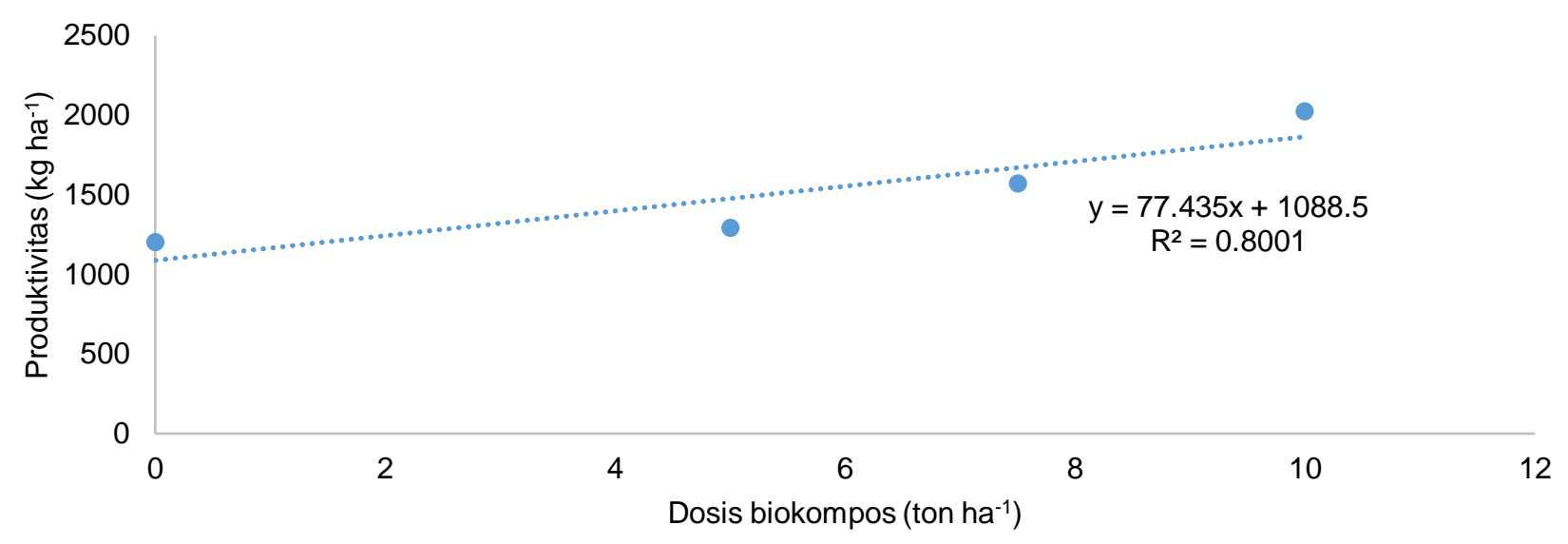

Gambar 6 Hasil analisis regresi linear pengaruh aplikasi biokompos pada rata-rata produktivitas kopi Arabika Gayo.

sedangkan pemupukan dengan dosis 10 ton $\mathrm{ha}^{-1}$ memperoleh produktivitas yang lebih rendah, yaitu $1862,85 \mathrm{~kg} \mathrm{ha}{ }^{-1}$. Berdasarkan hal ini maka dosis optimal adalah dosis tertinggi, yaitu 10 ton ha $^{-1}$ karena peningkatan dosis pemupukan pada penelitian ini berbanding lurus dengan peningkatan produktivitas kopi Arabika Gayo.

Aplikasi pupuk biourine100 mL plant ${ }^{1}+$ biokompos 10 ton ha-1 + NPK $100 \mathrm{~kg} \mathrm{ha}^{-1}$ (C4) pada tanaman kopi Arabika Gayo memberikan produktivitas yang lebih tinggi jika dibandingkan dengan aplikasi pupuk NPK $150 \mathrm{~kg} \mathrm{ha}^{-1}$ tanpa biourine dan biokompos (C1) karena biourine dan biokompos mengandung unsur hara makro dan mikro yang kompleks, mikroorgasisme, dan zat pengatur tumbuh (ZPT) yang tidak tersedia secara utuh pada pupuk NPK. Hasil penelitian Rinekso et al. (2011) menunjukkan bahwa fermentasi yang dilakukan selama 15 hari pada urine sapi Jatibarang mengadung unsur hara C-organik 4,49\%, N 0,7\%, P 0,16\%, K $0,62 \%$, dan $\mathrm{C} / \mathrm{N} 6,41$, sejalan dengan penelitian Hadisuwito (2012) yang menyatakan bahwa urine sapi mengandung unsur $\mathrm{N} 0,52 \%, \mathrm{P} 0,01 \%$, dan $\mathrm{K} 0,56 \%$. Selain itu, Huda (2013) menyatakan bahwa selain mengadung unsur hara, dalam biourine terdapat zat pengatur tumbuh dan senyawa penolak serangan serangga dan hama tanaman. Urine sapi juga mengandung zat pengatur tumbuh, seperti auksin (Pangaribuan et al. 2017). Kandungan unsur hara dan ZPT auksin pada biourine berperan secara optimal pada pertumbuhan vegetatif tanaman dan pembentukan jaringan meristem pada perakaran tanaman sehingga mampu menyerap unsur hara secara optimal untuk mendukung peningkatan produktivitas.

Biokompos kulit kopi mengandung unsur hara yang tergolong tinggi sehingga dapat mendukung secara langsung peningkatan produktivitas kopi Arabika Gayo. Penelitian Novita et al. (2018) tentang kandungan hara makro limbah kulit kopi menunjukkan bahwa kompos kulit kopi basah dan campuran mengandung sebesar $3,22 \%$ N, 1,09\% P, dan 1,76\% K. Ramli (2013) menunjukkan bahwa kompos kulit kopi mengandung kadar C-organik 80\%, N 4,73\%, P 0,21\%, dan K 2,89\%, serta mengandung unsur hara mikro $\mathrm{Ca}, \mathrm{Mg}, \mathrm{Mn}, \mathrm{Fe}$, $\mathrm{Cu}$, dan $\mathrm{Zn}$. Kandungan unsur hara makro yang tinggi mampu memenuhi kebutuhan hara tanaman selama proses pertumbuhan dan produksi tanaman.

Ketersedian unsur hara mikro dan mikroorganisme pada biokompos kopi merupakan salah satu faktor pendukung produktivitas tanaman kopi Arabika Gayo. Unsur mikro yang tersedia dalam biokompos merupakan unsur mikro esensial yang dibutuhkan tanaman dalam jumlah yang kecil, tetapi wajib tersedia selama proses pertumbuhan dan produksi tanaman. Kekurangan atau kelebihan unsur hara mikro esensial berpengaruh besar pada penurunan atau peningkatan pertumbuhan dan produktivitas tanaman. Unsur hara mikro Mn, Fe, Zn, dan Cu berperan aktif pada proses pembentukan protein, karbohidrat, dan lemak, merangsang pembentukan biji, merangsang pembentukan hormon tumbuh (auksin), dan resistensi terhadap organisme pengganggu tanaman. Unsur-unsur hara mikro yang terkandung dalam biokompos merupakan unsur hara yang memiliki peranan penting dalam proses produksi tanaman kopi Arabika Gayo.

$\mathrm{Zn}$ merupakan unsur hara mikro esensial dengan peran utama sebagai molekul pembantu enzim dalam transformasi biokimia untuk pembentukan asam nukleat, sintesis protein, dan pembelahan sel-sel jaringan meristem tanaman. Selain itu, $\mathrm{Zn}$ dapat meningkatkan resistensi tanaman terhadap serangan organisme penggangu tanaman (Sarwar 2011; Gogi et al. 2012). Unsur $\mathrm{Cu}$ berperan dalam sistem transportasi elektron hasil fotosintesis, metabolisme protein dan karbohidrat, dan fiksasi nitrogen dalam proses fisiologi (Sutiyoso 2006).

Hasil analisis tanah menunjukkan $\mathrm{pH}$ tanah yang tergolong rendah, yaitu 4,78-5,39 sehingga dapat memperlambat penyerapan hara tanaman dari dalam tanah. Aplikasi biourine dan biokompos dengan kandungan mikroorganisme dapat mempercepat pelarutan unsur hara sehingga dapat tersedia bagi tanaman. Kandungan mikroorganisme berperan sebagai pengurai bahan organik dan pelarut unsur hara yang tersedia dalam tanah setelah diaplikasikan. Isnaini (2006) menyatakan bahwa pelepasan unsur hara pupuk organik berbeda dari pupuk kimia, pelepasan unsur hara organik akan semakin baik apabila dibantu dengan aktivitas mikroorganisme. 
Letskona et al. (2013) menyatakan bahwa mikroorganisme mampu mempercepat ketersedian unsur hara fosfat melalui pelarutan unsur hara dari bentuk yang belum tersedia bagi tanaman menjadi unsur hara yang tersedia sehingga tanaman tidak kekurangan unsur fosfat yang sangat dibutuhkan pada masa pertumbuhan vegetatif sampai generatif. Ketersedian unsur hara yang tersedia akibat aktivitas mikroorganisme tanah dapat dimanfaatkan tanaman untuk mengoptimalkan potensi produktivitas.

Konsep integrasi biourine dan biokompos diharapkan mampu berperan secara menyeluruh pada pengelolaan budi daya kopi Arabika Gayo dengan peningkatan produktivitas kopi Arabika Gayo secara berkelanjutan, perbaikan kejenuhan, dan degradasi lahan dengan meminimalisir penggunaan pupuk anorganik.

\section{KESIMPULAN}

Perlakuan paket pemupukan biourine dan biokompos tidak berinteraksi dengan varietas Arabika Gayo I dan Gayo II, tetapi pemupukan biourine dan biokompos berpengaruh nyata pada produksi kopi Arabika Gayo. Pemupukan biourine $100 \mathrm{~mL}^{\text {plant }}{ }^{1}+$ biokompos 10 ton ha-1 + NPK $100 \mathrm{~kg} \mathrm{ha}^{-1}$ memberikan hasil terbaik dan mampu meningkatkan produksi tanaman sebesar $41 \%$ jika dibandingkan dengan pemupukan NPK $150 \mathrm{~kg} \mathrm{ha}^{-1}$ tanpa biourine dan biokompos.

\section{UCAPAN TERIMA KASIH}

Ucapan terima kasih penulis sampaikan kepada Badan Penelitian Pertanian (Balitbangtan) Kementerian Pertanian yang telah mendukung pendanaan penelitian ini melalui program KP4S Badan Litbang Pertanian.

\section{DAFTAR PUSTAKA}

Anggara AWE, Murdiono, Islami T. 2016. Pengaruh pemberian biourine dan pupuk anorganik terhadap pertumbuhan dan hasil tanaman buncis (Phaseolus vulgaris L.). Jurnal Produksi Tanaman. 4(5): 385-391.

Aribawa IB. 2008. Pengaruh Beberapa Jenis Pupuk Organik dan Pupuk Urea Terhadap Sifat Tanah dan Hasil Kacang Panjang di Lahan Kering Pinggiran Perkotaan Denpasar Bali. [internet] [diakses tanggal 31 Maret 2019]. Tersedia pada: www.deptan.go.id.

Atrisiandy K. 2015. Pemangkasan Kopi. Balai Pengkajian Teknologi Sumatera Utara. Medan (ID): BPTP Sumatera Utara.
Baon JBR, Sukasih, Nurkholis. 2005. Laju dekomposisi dan kualitas kompos limbah padat kopi: pengaruh aktivator dan bahan baku kompos. Pelita Perkebunan. 21: 31-42.

[BPPT] Balai Pengkajian Teknologi Pertanian Aceh. Deskripsi Kopi Arabika Gayo I dan Gayo II. Banda Aceh (ID): BPTP Aceh

Dharmayanti N, Supadma AAN, Arthagama IDM. 2013. Pengaruh pemberian biourine dan dosis pupuk anorganik (NPK) terhadap beberapa sifat kimia tanah pegok dan hasil tanaman bayam (Amaranthus sp.). E-Jurnal Agroekoteknologi Tropika. 2(3): 165-174.

[Dirjenbun] Direktorat Jenderal Perkebunan. 2017. Statistik Perkebunan Indonesia 2015-2017, Komoditas Kopi. Jakarta (ID): Kementerian Pertanian.

Dinas Kehutanan dan Perkebunan Kabupaten Bener Meriah. 2015. Data Luas Lahan Kopi dan Jumlah Petani di Kabupaten Bener Meriah. Redelong (ID): Dinas Kehutanan dan Perkebunan Kabupaten Bener Meriah.

Effendi D, Sufardi, Muyassir. 2014. Aplikasi biochar dan kompos kulit kopi untuk meningkatkan hasil kentang pada andisol atu lintang kabupaten Aceh Tengah. Jurnal Manajemen Sumberdaya Lahan. 3(2): 452-458.

Falahudin I, Anita RPR, Leket H. 2016. Pengaruh pupuk organik limbah kulit kopi (Coffea arabica L.) terhadap pertumbuhan bibit kopi. Jurnal Bioilmi. 2(2): 1-13.

Gogi MD, Arif JM, Asif M, Zain-ul-Abdin, Bashir MH, Ashad M, Khan MA, Abbas Q, Shahid MR, Anwar A. 2012. Impact of nutrient management schedules on infestation of Bemisia tabaci on yield of non-BT cotton (Gossypium hirsu-tum) under unsprayed condition. Pakistan Entomologist. 34(1): 87-92.

Hadisuwito S. 2012. Membuat Pupuk Organik Cair. Jakarta (ID): Agromedia Pustaka.

Huda MK. 2013. Pembuatan Pupuk Organik Cair dari Urine Sapi dengan Aditif Tetes Tebu (Molasses) Metode Fermentasi. [Skripsi]. Semarang (ID): Universitas Negeri Semarang.

Isnaini M. 2006. Pertanian Organik. Yogyakarta (ID): Kreasi Wacana.

Jaya R, Machfud, Ismail M. 2011. Aplikasi Teknik ISM dan ME-MCDM untuk identifikasi posisi pemangku kepentingan dan alternatif kegiatan untuk perbaikan mutu kopi Gayo. Jurnal Teknologi Industri Pertanian. 21(1): 1-8.

Jaya R, Machfud, Raharja S, Marimin. 2014. Analisis dan mitigasi resiko rantai pasok kopi gayo berkelanjutan dengan pendekatan fuzzy. Jurnal Teknologi Industri Pertanian. 24(1): 61-71. 
Leskona, Linda, Mukarlina. 2013. Pertumbuhan Jagung dengan Pemberian Glamus Agregatum dan Biofertilizer pada Tanah Bekas Penambangan Emas. Jurnal Protobion. 2(3): 176-180.

Novita E, Anis F, Hendra AP. 2018. Pemanfaatan kompos blok limbah kulit kopi sebagai media tanam. Jurnal Agrotek. 2(2): 61-72. https://doi.org/ 10.33096/agrotek.v2i2.62

Pangaribuan DH, Sarno, Kurniawan MC. 2017. Pengaruh pupuk cair urine sapi terhadap pertumbuhan dan produksi tanaman jagung manis (Zea mays L.). Jurnal Metamorfosa. 4(2): 202-209. https://doi.org/10.24843/METAMORFOSA.2017.v0 4.i02.p11

Panggabean E. 2011. Buku Pintar Kopi. Jakarta (ID): Agromedia Pustaka.

Putro BP, Walidaini RA, Samudro G, Nugraha WD. 2016. Peningkatan kualitas kompos sampah organik kampus dengan diperkaya pupuk NPK dan urea. Dalam: Prosiding SNST ke-7. Semarang (ID): Universitas Wahid Hasyim.

Ramli. 2013. Pengaruh kompos kulit buah kopi terhadap pertumbuhan dan hasil tanaman petsai pada tanah alluvial. Junal Sains Mahasiswa Pertanian. 3(1): 1-13.

Rinanto H, Azizah N, Santosa M. 2015. Pengaruh Aplikasi Kombinasi biourine dengan Pupuk Organik dan Anorganik Terhadap Pertumbuhan dan Hasil tanaman Bawang Merah (Allium ascalonicum L). Jurnal Produksi Tanaman. 3(7): 581-589

Rinekso K B, Sutrisno E, Sumiyati S. 2011. Studi Pembuatan Pupuk Organik Cair dari Fermentasi Urine Sapi (Ferisa) dengan Variasi Lokasi Peternakan yang Berbeda. BJM [Internet]. [diunduh 05 Juli 2020]. Tersedia pada http://eprints.undip.ac.id/42243/.

Sarwar M. 2011. Effects of zinc fertilizer application on theincidence of rice stem borers (Scirpophaga species) (Lepidoptera: Pyralidae) in rice (Oryza sativa L.) crop. Journal of Cereals and Oilseeds. 2(5): 61-65.

Simajuntak A, Ratna RL, Edison P. 2013. Respon pertumbuhan dan produksi bawang merah (Allium ascalonicum L.) terhadap pemberian pupuk NPK dan kompos kulit buah kopi. Jurnal Online Agroekoteknologi. 1(3): 2337-6597.

Sutiyoso Y. 2006. Hidroponik Ala Yos. Jakarta (ID): Penebar Swadaya

Valentiah FV, Endang L, Sugeng P. 2015. Aplikasi kompos kulit kopi untuk perbaikan sifat kimia dan fisika tanah inceptisol serta meningkatkan produksi brokoli. Jurnal Tanah dan Sumberdaya Lahan. 2(1): 147-154.

Wati YT, Nurlaelih EE, Santosa M. 2014. Pengaruh Aplikasi Biourin Pada Pertumbuhan dan Hasil Tanaman Bawang Merah (Allium ascolanicum L). Jurnal Produksi Tanaman. 2(8): 613-619. 